\title{
PENGARUH IKLIM ORGANISASI, MOTIVASI KERJA DAN KEPUASAN KERJA TERHADAP KINERJA PEGAWAI DI KANTOR WILAYAH DIREKTORAT JENDERAL PAJAK SUMATERA UTARA I
}

\author{
Kristina Romauli \\ Universitas Islam Sumatera Utara \\ krisna.romauli@gmail.com
}

\begin{abstract}
The formulation of the problem in this research is how the influence of organization climate on employees performance. How influence of work motivation on employees performance. How influence of work satisfaction on employees performance. How influence of organization climate, work motivation and work satisfaction on employees performance. The purpose of this research is for know influence and analize of organization climate on employees performance. For know influence and analize of work motivation on employees performance. For know influence and analize work satisfaction on employees performance. For know influence and analize organization climate, work motivation and work satisfaction on employees performance. The sample in this research is 95 employees, with data analysis technique used is multiple linear regression analyze. The results of this research explain that organization climate effect has a positive and significant on employee performance. Work motivation effect has a positive and significant on employee performance. work satisfaction effect has a positive and significant on employee performance. Organization climate, work motivation and work satisfaction effect have a positive and significant on employee performance.
\end{abstract}

Keywords : Organization climate, Work Motivation, Work Satisfaction, Performance

ABSTRAK : Rumusan masalah dalam penelitian ini adalah bagaimana pengaruh iklim organisasi terhadap kinerja pegawai. Bagaimana pengaruh motivasi kerja terhadap kinerja pegawai. Bagaimana pengaruh kepuasan kerja terhadap kinerja pegawai. Bagaimana pengaruh iklim organisasi, motivasi kerja dan kepuasan kerja terhadap kinerja pegawai.

Tujuan penelitian ini adalah untuk mengetahui dan menganalisis pengaruh iklim organisasi terhadap kinerja pegawai. Untuk mengetahui dan menganalisis pengaruh motivasi kerja terhadap kinerja pegawai. Untuk mengetahui dan menganalisis pengaruh kepuasan kerja terhadap kinerja pegawai. Untuk mengetahui dan menganalisis pengaruh iklim organisasi, motivasi kerja dan kepuasan kerja terhadap kinerja pegawai

Sampel dalam penelitian ini berjumlah 95 orang pegawai. Teknik analisis data dalam penelitian ini menggunakan analisis deskriptif dan analisis regresi linier berganda.

Hasil penelitian ini menjelaskan bahwa iklim organisasi berpengaruh positif dan signifikan terhadap kinerja pegawai. Motivasi kerja berpengaruh positif dan signifikan terhadap kinerja pegawai. Kepuasan kerja berpengaruh positif dan signifikan terhadap kinerja pegawai. Iklim organisasi, motivasi kerja dan kepuasan kerja berpengaruh positif dan signifikan terhadap kinerja pegawai

Kata kunci : Iklim organisasi, Motivasi Kerja, Kepuasan Kerjas, Kinerja Pegawai

\section{Pendahuluan}

Aset terpenting dalam suatu instansi adalah sumber daya manusia atau pegawai, tanpa mereka betapa sulitnya instansi mencapai tujuan, yang menentukan maju mundurnya suatu instansi, dengan memiliki tenaga-tenaga kerja yang terampil dengan motivasi tinggi instansi telah mempunyai aset yang sangat mahal, sebab pada dasarnya manusia merupakan subyek dan obyek pembangunan yang merupakan faktor yang sangat penting, terutama peningkatan kualitas sumber daya manusia menjadi prioritas yang utama. Kantor Wilayah Direktorat Jenderal Pajak Sumatera 
Utara I merupakan suatu instansi yang melakukan pembinaan, pengawasan dalam pembayaran pajak, dimana keberhasilan pelaksanaan tugas dan tanggung jawab dalam instansi tergantung pada kinerja para pegawai yang ada di instansi tersebut. Pentingnya kinerja pegawai yang ada pada Kantor Wilayah Direktorat Jenderal Pajak Sumatera Utara I sangat berpengaruh terhadap pelaksanaan tujuan instansi itu, yaitu untuk meningkatkan pelayanan terhadap para masyarakat terutama dalam penanggulangan bencana, dan peranan Pegawai Negeri Sipil sebagai unsur aparatur negara yang bertugas sebagai abdi masyarakat harus menyelenggarakan pelayanan secara adil kepada masyarakat dengan dilandasi kesetiaan dan ketaatan kepada Pancasila dan UndangUndang Dasar 1945. Dalam hal pencapaian tugas dengan baik, maka pembinaan pegawai diarahkan untuk meningkatkan kualitas sumber daya manusia agar memiliki kapabilitas dan kinerja sebagai pelayan masyarakat sesuai tuntutan perkembangan masyarakat.

Kinerja yang baik dan hasil kerja yang meningkat di suatu organisasi kerja, pegawai harus memenuhi persyaratan atau memiliki diantaranya keahlian dan kemampuan dasar, yaitu sekelompok kemampuan, yang meliputi kemampuan komunikasi, kemampuan teknik, kemampuan konseptual, serta kualitas pribadi yang meliputi mental, fisik, emosi, watak sosial, sikap, komitmen, integritas, kesadaran, serta perilaku yang baik, dan kemampuan administrasi meliputi kemampuan menganalisis persoalan, memberi pertimbangan, pendapat, keputusan, mengatur sumber daya, dan berbagai macam kegiatan, lapang dada, sabar, berpartisipasi aktif dalam berbagai aktivitas. Robbins (2006:170).

Faktor lain yang mempengaruhi kinerja adalah motivasi kerja. Abdullah (2013:112) dalam penelitiannya menyatakan bahwa $30 \%$ dari waktu para pimpinan digunakan untuk mengurusi masalah motivasi kerja. Pendekatan yang digunakan dalam memberikan motivasi kerja pada pegawai perlu memperhatikan karesteristik pegawai yang bersangkutan. Studi empiris yang dilakukan oleh Altangerel (2015:143) membandingkan antara karyawan dan supervisor sektor publik dan swasta memberikan hasil yang berbeda. Pada pegawai sektor publik lebih cendrung motivasi kerja mereka disebabkan oleh adanya kestabilan dan keamanan dalam bekerja dimasa mendatang sebagai faktor utama yang berpengaruh. Sedangkan untuk karyawan sektor swasta motivasi mereka bekerja sangat dipengaruhi oleh tingginya gaji yang mereka peroleh dan kesempatan untuk meraih jenjang yang lebih tinggi.

Hasil survei penelitian di Kantor Wilayah Direktorat Jenderal Pajak Sumatera Utara I ditemukan bahwa motivasi kerja pegawai bekerja masih belum optimal, hal ini dapat kemungkinan disebabkan karena kondisi pegawai yang merasa jenuh dalam bekerja, atau kurangnya program yang dapat meningkatkan kinerja pegawai. Sebab dalam suatu organisasi motivasi kerja pegawai sangat diperlukan untuk mencapai suatu tujuan yang telah ditetapkan bersama. Menurut Hasibuan (2008:99) kemampuan dan kecakapan yang dimiliki pegawai tidak ada artinya bagi organisasi jika mereka tidak termotivasi untuk bekerja. Motivasi yang ada pada diri seseorang merupakan kekuatan pendorong yang akan mewujudkan suatu perilaku guna mencapai tujuan kepuasan (dirinya). Karena motivasi sebagai kesediaan untuk mengeluarkan tingkat upaya yang tinggi untuk tujuan organisasi yang dikondisikan oleh kemampuan upaya dalam memenuhi beberapa kebutuhan individu. Apabila motivasi untuk melaksanakan perkerjaan tinggi, diharapkan hasil kinerja akan maksimal. Sebaliknya motivasi kerja rendah, maka kinerja yang dihasilkan tidak akan optimal.

Di sisi lain, dalam menjalankan tugas sesuai dengan fungsinya, maka kinerja pegawai juga akan ditentukan oleh bagaimana pegawai tersebut merasa puas atau tidak terhadap seluruh keputusan instansi. Kepuasan kerja selalu dikaitkan dengan kinerja pegawai. Hal ini berarti untuk dapat meningkatkan kinerja pegawai, organisasi harus mampu memenuhi dan meningkatkan kepuasan kerja pegawainya. Terry (2011:111) menyatakan bahwa kepuasan kerja adalah seperangkat perilaku kerja positif yang berakar pada kesadaran yang kental, keyakinan yang fundamental, disertai komitmen yang total pada paradigma kerja yang integral. Istilah paradigma di sini berarti konsep utama tentang kerja itu sendiri yang mencakup idealisme yang mendasari, prinsip-prinsip yang mengatur, nilai-nilai yang menggerakkan, sikap-sikap yang dilahirkan, standar-standar yang hendak dicapai. termasuk karakter utama, pikiran dasar, kode etik, kode moral, dan kode perilaku bagi 
para pemeluknya. Penelitian dari Noviansyah dan Zunaidah (2011) menyatakan kepuasan kerja berpengaruh positif dan signifkan terhadap kinerja.

Faktor lain yang diduga mempengaruhi kinerja pegawai adalah iklim organisasi. Robbins (2007:88) memandang iklim organisasi sebagai kepribadian sebuah organisasi yang membedakan dengan organisasi lainnya yang mengarah pada persepsi masing-masing anggota dalam memandang organisasi. Jadi dapat disimpulkan bahwa iklim organisasi adalah serangkaian deskripsi dari karakteristik organisasi yang membedakan sebuah organisasi dengan organisasi lainnya yang mengarah pada persepsi masing-masing anggota dalam memandang organisasi. Fenomena tentang iklim organisasi pegawai Kantor Wilayah Direktorat Jenderal Pajak Sumatera Utara I diantaranya kesempatan dan keterlibatan pegawai khususnya staf dalam memberikan masukan kepada atasan masih kurang optimal.

Adapun tujuan penelitian ini adalah sebagai berikut:

1. Untuk menganalisis pengaruh iklim organisasi terhadap kinerja pegawai di Kantor Wilayah Direktorat Jenderal Pajak Sumatera Utara I.

2. Untuk menganalisis pengaruh motivasi kerja terhadap kinerja pegawai di Kantor Wilayah Direktorat Jenderal Pajak Sumatera Utara I.

3. Untuk menganalisis pengaruh kepuasan kerja terhadap kinerja pegawai di Kantor Wilayah Direktorat Jenderal Pajak Sumatera Utara I.

4. Untuk mengetahui dan menganalisis pengaruh iklim organisasi, motivasi kerja dan kepuasan kerja terhadap kinerja pegawai di Kantor Wilayah Direktorat Jenderal Pajak Sumatera Utara I.

\section{Metode Penelitian \\ 2.1. Populasi dan Sampel}

Menurut Sugiyono (2004:90) populasi adalah wilayah generalisasi yang terdiri dari atas objek/subjek yang mempunyai kualitas karakteristik tertentu yang disajikan oleh peneliti untuk dipelajari dan kemudian ditarik kesimpulannya. Adapun yang menjadi populasi dalam penelitian ini adalah pegawai Kantor Wilayah Direktorat Jenderal Pajak Sumatera Utara I yang berjumlah 125 orang.

Penentuan jumlah sampel pada penelitian menggunakan pendekatan Slovin, dengan metode Stratified Random Sampling, maka jumlah sampel sebanyak 95 orang.

\subsection{Pengujian Validitas}

Uji validitas digunakan untuk mengukur sah atau valid tidaknya suatu kuesioner. Suatu kuesioner dikatakan valid jika pertanyaan pada kuesioner mampu untuk mengungkapkan sesuatu yang akan diukur oleh kuesioner tersebut. Metode yang digunakan untuk menguji validitas adalah melakukan korelasi antar skor butir pertanyaan dengan total skor konstruk atau variabel. Pengujian validitas dilakukan dengan melakukan korelasi bilvariate antara masing-masing skor indikator dengan total skor konstruk. Hasil analisis korelasi bilvariate dengan melihat output Pearson Correlation, dengan ketentuan :

1. $r$ hitung $>r$ tabel, maka instrumen yang digunakan dinyatakan valid.

2. $r$ hitung $<\mathrm{r}$ tabel, maka instrumen yang digunakan dinyatakan tidak valid.

Tabel 1

Uji Validitas Instrumen Iklim Organisasi

\begin{tabular}{|c|c|c|c|c|}
\hline Variabel & Angket & $\mathrm{r}_{\mathrm{tbl}}>0.207$ & Sig < 0.05 & Keterangan \\
\hline \multirow{4}{*}{$\begin{array}{c}\text { Iklim Organisasi } \\
\left(\mathrm{X}_{1}\right)\end{array}$} & $\mathrm{X}_{1.1}$ & 0.742 & 0.000 & Valid \\
\cline { 2 - 5 } & $\mathrm{X}_{1.2}$ & 0.823 & 0.000 & Valid \\
\cline { 2 - 5 } & $\mathrm{X}_{1.3}$ & 0.509 & 0.000 & Valid \\
\cline { 2 - 5 } & $\mathrm{X}_{1.4}$ & 0.497 & 0.000 & Valid \\
\cline { 2 - 5 } & $\mathrm{X}_{1.5}$ & 0.715 & 0.000 & Valid \\
\cline { 2 - 5 } & $\mathrm{X}_{1.6}$ & 0.341 & 0.001 & Valid \\
\cline { 2 - 5 } & $\mathrm{X}_{1.7}$ & 0.740 & 0.000 & Valid \\
\cline { 2 - 5 } & $\mathrm{X}_{1.8}$ & 0.648 & 0.000 & Valid \\
\cline { 2 - 5 } & $\mathrm{X}_{1.9}$ & 0.659 & 0.000 & Valid \\
\cline { 2 - 5 } & $\mathrm{X}_{1.10}$ & 0.716 & 0.000 & Valid \\
\hline
\end{tabular}

Sumber : Hasil Pengolahan SPSS Versi 20

Tabel 1 diatas menunjukkan bahwa seluruh indikator pada setiap variabel telah memenuhi syarat validitas, yaitu $r$ hitung $>r$ tabel, dimana

$\mathrm{r}$ tabel $=0.207$. Oleh sebab itu, indikatorindikator tersebut dapat digunakan untuk mengukur variabel penelitian. 
Tabel 2

Uji Validitas Instrumen Motivasi Kerja

\begin{tabular}{|c|c|c|c|c|}
\hline Variabel & Angket & $\mathrm{r}_{\text {tbl }}>0.207$ & Sig < 0.05 & Keterangan \\
\hline \multirow{5}{*}{$\begin{array}{c}\text { Motivasi Kerja } \\
\left(\mathrm{X}_{2}\right)\end{array}$} & $\mathrm{X}_{2.1}$ & 0.435 & 0.000 & Valid \\
\cline { 2 - 5 } & $\mathrm{X}_{2.2}$ & 0.503 & 0.000 & Valid \\
\cline { 2 - 5 } & $\mathrm{X}_{2.3}$ & 0.564 & 0.000 & Valid \\
\cline { 2 - 5 } & $\mathrm{X}_{2.4}$ & 0.598 & 0.000 & Valid \\
\cline { 2 - 5 } & $\mathrm{X}_{2.5}$ & 0.581 & 0.000 & Valid \\
\cline { 2 - 5 } & $\mathrm{X}_{2.6}$ & 0.590 & 0.002 & Valid \\
\cline { 2 - 5 } & $\mathrm{X}_{2.7}$ & 0.625 & 0.000 & Valid \\
\cline { 2 - 5 } & $\mathrm{X}_{2.8}$ & 0.765 & 0.000 & Valid \\
\cline { 2 - 5 } & $\mathrm{X}_{2.9}$ & 0.625 & 0.000 & Valid \\
\cline { 2 - 5 } & $\mathrm{X}_{2.10}$ & 0.651 & 0.000 & Valid \\
\hline
\end{tabular}

Sumber : Hasil Pengolahan SPSS Versi 20

Tabel 2, diatas menunjukkan bahwa seluruh $\mathrm{r}$ tabel $=0.207$. Oleh sebab itu, indikator indikator pada setiap variabel telah memenuhi indikator tersebut dapat digunakan untuk syarat validitas, yaitu $r$ hitung $>r$ tabel, dimana mengukur variabel penelitian.

Tabel 3

Uji Validitas Instrumen Kepuasan Kerja

\begin{tabular}{|c|c|c|c|c|}
\hline Variabel & Angket & $\mathrm{r}_{\mathrm{tbl}}>0.207$ & Sig < 0.05 & Keterangan \\
\hline \multirow{5}{*}{$\begin{array}{c}\text { Kepuasan Kerja } \\
\left(\mathrm{X}_{3}\right)\end{array}$} & $\mathrm{X}_{3.1}$ & 0.748 & 0.000 & Valid \\
\cline { 2 - 5 } & $\mathrm{X}_{3.2}$ & 0.862 & 0.000 & Valid \\
\cline { 2 - 5 } & $\mathrm{X}_{3.3}$ & 0.546 & 0.000 & Valid \\
\cline { 2 - 5 } & $\mathrm{X}_{3.4}$ & 0.604 & 0.000 & Valid \\
\cline { 2 - 5 } & $\mathrm{X}_{3.5}$ & 0.774 & 0.000 & Valid \\
\cline { 2 - 5 } & $\mathrm{X}_{3.6}$ & 0.325 & 0.001 & Valid \\
\cline { 2 - 5 } & $\mathrm{X}_{3.7}$ & 0.779 & 0.000 & Valid \\
\cline { 2 - 5 } & $\mathrm{X}_{3.8}$ & 0.693 & 0.000 & Valid \\
\cline { 2 - 5 } & $\mathrm{X}_{3.9}$ & 0.657 & 0.000 & Valid \\
\cline { 2 - 5 } & $\mathrm{X}_{3.10}$ & 0.768 & 0.000 & Valid \\
\hline
\end{tabular}

Sumber : Hasil Pengolahan SPSS Versi 20

Tabel 3. diatas menunjukkan bahwa seluruh indikator pada setiap variabel telah memenuhi syarat validitas, yaitu $\mathrm{r}$ hitung > r tabel, dimana

$\mathrm{r}$ tabel $=0.207$. Oleh sebab itu, indikator indikator tersebut dapat digunakan untuk mengukur variabel penelitian.

Tabel 4

Uji Validitas Instrumen Kinerja

\begin{tabular}{|c|c|c|c|c|}
\hline Variabel & Angket & $\mathrm{r}_{\mathrm{tbl}}>0.207$ & Sig < 0.05 & Keterangan \\
\hline \multirow{6}{*}{$\begin{array}{c}\text { Kinerja } \\
\text { (Y) }\end{array}$} & $\mathrm{Y}_{1}$ & 0.773 & 0.000 & Valid \\
\cline { 2 - 5 } & $\mathrm{Y}_{2}$ & 0.693 & 0.000 & Valid \\
\cline { 2 - 5 } & $\mathrm{Y}_{3}$ & 0.651 & 0.000 & Valid \\
\cline { 2 - 5 } & $\mathrm{Y}_{4}$ & 0.443 & 0.000 & Valid \\
\cline { 2 - 5 } & $\mathrm{Y}_{5}$ & 0.436 & 0.000 & Valid \\
\cline { 2 - 5 } & $\mathrm{Y}_{6}$ & 0.657 & 0.000 & Valid \\
\cline { 2 - 5 } & $\mathrm{Y}_{7}$ & 0.475 & 0.000 & Valid \\
\cline { 2 - 5 } & $\mathrm{Y}_{8}$ & 0.787 & 0.000 & Valid \\
\cline { 2 - 5 } & $\mathrm{Y}_{9}$ & 0.861 & 0.000 & Valid \\
\cline { 2 - 5 } & $\mathrm{Y}_{10}$ & 0.317 & 0.002 & Valid \\
\hline
\end{tabular}

Sumber : Hasil Pengolahan SPSS Versi 20

Tabel 4. diatas menunjukkan bahwa seluruh indikator pada setiap variabel telah memenuhi syarat validitas, yaitu $r$ hitung $>r$ tabel, dimana $\mathrm{r}$ tabel $=0.207$. Oleh sebab itu, indikator indikator tersebut dapat digunakan untuk mengukur variabel penelitian. 


\subsection{Uji Reliabilitas}

Untuk mengetahui kestabilan dan konsisten responden dalam menjawab butir-butir berkaitan dengan konstruk pertanyaan yang disusun dalam bentuk quisioner. Reliabilitas suatu konstruk variabel dikatakan baik jika memiliki nilai Cronbach's alpha lebih besar (>) 0,60 (Rusiadi, et al. 2013:127).

Reliabilitas dari pertanyaan angket yang telah diajukan penulis kepada responden dalam penelitian ini akan terlihat pada tabel ReliabilityStatistics yang disajikan dalam tabel dibawah ini:

Tabel 5

Uji Reliabilitas Variabel Iklim Organisasi Reliability Statistics

\begin{tabular}{|c|c|}
\hline $\begin{array}{c}\text { Cronbach's } \\
\text { Alpha }\end{array}$ & N of Items \\
\hline 0.842 & 10 \\
\hline
\end{tabular}

Item-Total Statistics

\begin{tabular}{|c|c|c|c|c|}
\hline Angket & $\begin{array}{c}\text { Scale Mean if } \\
\text { Item Deleted }\end{array}$ & $\begin{array}{c}\text { Scale Variance } \\
\text { if Item Deleted }\end{array}$ & $\begin{array}{c}\text { Corrected } \\
\text { Item-Total } \\
\text { Correlation }\end{array}$ & $\begin{array}{c}\text { Cronbach's } \\
\text { Alpha if Item } \\
\text { Deleted }\end{array}$ \\
\hline $\mathrm{X}_{1.1}$ & 40.4316 & 9.801 & .653 & .816 \\
\hline $\mathrm{X}_{1.2}$ & 40.6526 & 9.314 & .752 & .805 \\
\hline $\mathrm{X}_{1.3}$ & 40.5789 & 10.948 & .392 & .840 \\
\hline $\mathrm{X}_{1.4}$ & 40.3684 & 10.852 & .364 & .843 \\
\hline $\mathrm{X}_{1.5}$ & 40.6947 & 9.874 & .617 & .819 \\
\hline $\mathrm{X}_{1.6}$ & 40.6632 & 11.524 & .203 & .855 \\
\hline $\mathrm{X}_{1.7}$ & 40.5474 & 9.591 & .641 & .817 \\
\hline $\mathrm{X}_{1.8}$ & 40.7053 & 10.508 & .556 & .826 \\
\hline $\mathrm{X}_{1.9}$ & 40.6000 & 10.413 & .567 & .825 \\
\hline $\mathrm{X}_{1.10}$ & 40.5158 & 10.231 & .636 & .819 \\
\hline Sumber : Hasil Pengolahan SPSS Versi 20 & & \\
\hline
\end{tabular}

Diketahui nilai $r_{\text {tabel }}$ untuk uji dua sisi pada tingkat signifikan 5\% $(\mathrm{a}=0,05)$, dengan jumlah sample $\mathrm{N}=95$, maka derajat bebasnya adalah $\mathrm{N}$ $-3=95-3=92$, dan diketahui nilai $\mathrm{r}_{\text {tabel }}=$ 0.207. Dari hasil tabel di atas dapat terlihat bahwa nilai $r$ hitung pada kolom cronbach's alpha if item deleted semua lebih besar dari nilai $r_{\text {tabee }}$, maka seluruh butir pertanyaan untuk variable iklim organisasi dinyatakan reliabel, begitu juga halnya pada tabel reliability statistics diketahui nilai Alpha Cronbach Item-Total Statistics

\begin{tabular}{|c|c|c|c|c|}
\hline Angket & $\begin{array}{c}\text { Scale Mean if } \\
\text { Item Deleted }\end{array}$ & $\begin{array}{c}\text { Scale Variance } \\
\text { if Item Deleted }\end{array}$ & $\begin{array}{c}\text { Corrected } \\
\text { Item-Total } \\
\text { Correlation }\end{array}$ & $\begin{array}{c}\text { Cronbach's } \\
\text { Alpha if Item } \\
\text { Deleted }\end{array}$ \\
\hline $\mathrm{X}_{2.1}$ & 38.0632 & 14.570 & .211 & .800 \\
\hline $\mathrm{X}_{2.2}$ & 37.7263 & 14.116 & .450 & .766 \\
\hline $\mathrm{X}_{2.3}$ & 37.1263 & 14.409 & .435 & .768 \\
\hline $\mathrm{X}_{2.4}$ & 37.3579 & 12.807 & .369 & .788 \\
\hline $\mathrm{X}_{2.5}$ & 37.6211 & 13.217 & .456 & .765 \\
\hline $\mathrm{X}_{2.6}$ & 37.0000 & 14.553 & .457 & .767 \\
\hline $\mathrm{X}_{2.7}$ & 37.0526 & 13.157 & .582 & .749 \\
\hline $\mathrm{X}_{2.8}$ & 36.9789 & 13.829 & .661 & .749 \\
\hline $\mathrm{X}_{2.9}$ & 37.1789 & 12.766 & .572 & .749 \\
\hline $\mathrm{X}_{2.1}$ & 38.0632 & 14.570 & .211 & .800 \\
\hline
\end{tabular}

Sumber : Hasil Pengolahan SPSS Versi 20

Diketahui nilai $\mathrm{r}_{\text {tabel }}$ untuk uji dua sisi pada tingkat signifikan 5\% $(\mathrm{a}=0,05)$, dengan jumlah sebesar 0,842. Karena nilai Alpha Cronbach > $r_{\text {tabel}}$, maka angket yang digunakan reliabel.

Tabel 6

Uji Reliabilitas Variabel Motivasi Kerja Reliability Statistics

\begin{tabular}{|c|c|}
\hline $\begin{array}{c}\text { Cronbach's } \\
\text { Alpha }\end{array}$ & N of Items \\
\hline 0.784 & 10 \\
\hline
\end{tabular}


0.207. Dari hasil tabel di atas dapat terlihat bahwa nilai $r$ hitung pada kolom cronbach's alpha if item deleted semua lebih besar dari nilai $r_{\text {tabel }}$, maka seluruh butir pertanyaan untuk variable motivasi kerja dinyatakan reliabel, begitu juga halnya pada tabel reliability statistics diketahui nilai Alpha Cronbach sebesar 0,784. Karena nilai Alpha Cronbach > $\mathrm{r}_{\text {tabel}}$, maka angket yang digunakan reliabel.

Item-Total Statistics

\begin{tabular}{|c|c|c|c|c|}
\hline Angket & $\begin{array}{c}\text { Scale Mean if } \\
\text { Item Deleted }\end{array}$ & $\begin{array}{c}\text { Scale Variance } \\
\text { if Item Deleted }\end{array}$ & $\begin{array}{c}\text { Corrected } \\
\text { Item-Total } \\
\text { Correlation }\end{array}$ & $\begin{array}{c}\text { Cronbach's } \\
\text { Alpha if Item } \\
\text { Deleted }\end{array}$ \\
\hline $\mathrm{X}_{3.1}$ & 40.5053 & 10.253 & .662 & .853 \\
\hline $\mathrm{X}_{3.2}$ & 40.7474 & 9.638 & .807 & .839 \\
\hline $\mathrm{X}_{3.3}$ & 40.7053 & 11.359 & .437 & .870 \\
\hline $\mathrm{X}_{3.4}$ & 40.3684 & 11.554 & .530 & .864 \\
\hline $\mathrm{X}_{3.5}$ & 40.8105 & 10.070 & .692 & .850 \\
\hline $\mathrm{X}_{3.6}$ & 40.7789 & 12.174 & .195 & .886 \\
\hline $\mathrm{X}_{3.7}$ & 40.5895 & 10.032 & .698 & .850 \\
\hline $\mathrm{X}_{3.8}$ & 40.8526 & 10.935 & .614 & .857 \\
\hline $\mathrm{X}_{3.9}$ & 40.7368 & 10.962 & .567 & .861 \\
\hline $\mathrm{X}_{3.1}$ & 40.5053 & 10.253 & .662 & .853 \\
\hline Sumber $\cdot$ Hasil Pengolahan SPSS Versi 20 & & \\
\hline
\end{tabular}

Diketahui nilai $r_{\text {tabel }}$ untuk uji dua sisi pada tingkat signifikan 5\% $(\mathrm{a}=0,05)$, dengan jumlah sample $\mathrm{N}=95$, maka derajat bebasnya adalah $\mathrm{N}$ $-3=95-3=92$, dan diketahui nilai $\mathrm{r}_{\text {tabel }}=$ 0.207. Dari hasil tabel di atas dapat terlihat bahwa nilai $\mathrm{r}$ hitung pada kolom cronbach's alpha if item deleted semua lebih besar dari nilai $r_{\text {tabel }}$, maka seluruh butir pertanyaan untuk variable kepuasan kerja dinyatakan reliabel, begitu juga halnya pada tabel reliability statistics diketahui nilai Alpha Cronbach Item-Total Statistics

\begin{tabular}{|c|c|c|c|c|}
\hline Angket & $\begin{array}{c}\text { Scale Mean if } \\
\text { Item Deleted }\end{array}$ & $\begin{array}{c}\text { Scale Variance } \\
\text { if Item Deleted }\end{array}$ & $\begin{array}{c}\text { Corrected } \\
\text { Item-Total } \\
\text { Correlation }\end{array}$ & $\begin{array}{c}\text { Cronbach's } \\
\text { Alpha if Item } \\
\text { Deleted }\end{array}$ \\
\hline$Y_{1}$ & 39.5158 & 7.976 & .699 & .757 \\
\hline$Y_{2}$ & 39.4737 & 8.188 & .598 & .768 \\
\hline$Y_{3}$ & 39.3579 & 8.296 & .545 & .774 \\
\hline$Y_{4}$ & 39.8421 & 8.666 & .247 & .816 \\
\hline$Y_{5}$ & 39.3263 & 8.988 & .296 & .800 \\
\hline$Y_{6}$ & 39.4842 & 8.061 & .534 & .774 \\
\hline$Y_{7}$ & 39.7789 & 8.834 & .335 & .797 \\
\hline$Y_{8}$ & 39.2947 & 7.891 & .716 & .754 \\
\hline$Y_{9}$ & 39.4000 & 7.626 & .810 & .743 \\
\hline$Y_{10}$ & 39.4842 & 9.316 & .149 & .819 \\
\hline
\end{tabular}
Sumber : Hasil Pengolahan SPSS Versi 20

Diketahui nilai $r_{\text {tabel }}$ untuk uji dua sisi pada tingkat signifikan 5\% $(\mathrm{a}=0,05)$, dengan jumlah sample $\mathrm{N}=95$, maka derajat bebasnya adalah $\mathrm{N}$
Tabel 2.7

Uji Reliabilitas Variabel Kepuasan Kerja Reliability Statistics

\begin{tabular}{|c|c|}
\hline $\begin{array}{c}\text { Cronbach's } \\
\text { Alpha }\end{array}$ & N of Items \\
\hline 0.871 & 10 \\
\hline
\end{tabular}

sebesar 0,871. Karena nilai Alpha Cronbach > $\mathrm{r}_{\text {tabel }}$, maka angket yang digunakan reliabel.

Tabel 8

Uji Reliabilitas Variabel Kinerja Reliability Statistics

\begin{tabular}{|c|c|}
\hline $\begin{array}{c}\text { Cronbach's } \\
\text { Alpha }\end{array}$ & N of Items \\
\hline 0.799 & 10 \\
\hline
\end{tabular}


alpha if item deleted semua lebih besar dari nilai $r_{\text {tabel }}$, maka seluruh butir pertanyaan untuk variable kinerja dinyatakan reliabel, begitu juga halnya pada tabel reliability statistics diketahui nilai Alpha Cronbach sebesar 0,799. Karena nilai Alpha Cronbach $>\mathrm{r}_{\text {tabel }}$, maka angket yang digunakan reliabel.

\subsection{Uji Asumsi Klasik}

\subsubsection{Uji Normalitas}

Uji normalitas adalah untuk melihat apakah nilai residual terdistribusi normal atau tidak. Model regresi yang baik adalah memiliki nilai residual yang terdistribusi normal. Jadi uji normalitas bukan dilakukan pada masing masing variabel tetapi pada nilai residualnya. Sering terjadi kesalahan yang jamak yaitu bahwa uji normalitas dilakukan pada masing masing variabel. Hal ini tidak dilarang tetapi model regresi memerlukan normalitas pada nilai residualnya bukan pada masing-masing variabel penelitian. Pengujian normalitas data penelitian adalah untuk menguji apakah dalam model statistik variabel-variabel penelitian berdistribusi normal atau tidak normal. Model regresi yang tinggi adalah memiliki distribusi normal atau mendekati normal. Untuk menguji apakah distribusi data normal atau tidak, salah satunya dengan menggunakan metode gambar normal Probabilitas Plots digunakan untuk menyimpulkan apakah model analisis memenuhi asumsi normal, dengan penyebaran data di sekitar garis diagonal dan mengikuti arah garis diagonal maka data tersebut mememenuhi asumsi normal dalam model analisis, yang dapat dilihat pada gambar dibawah ini :

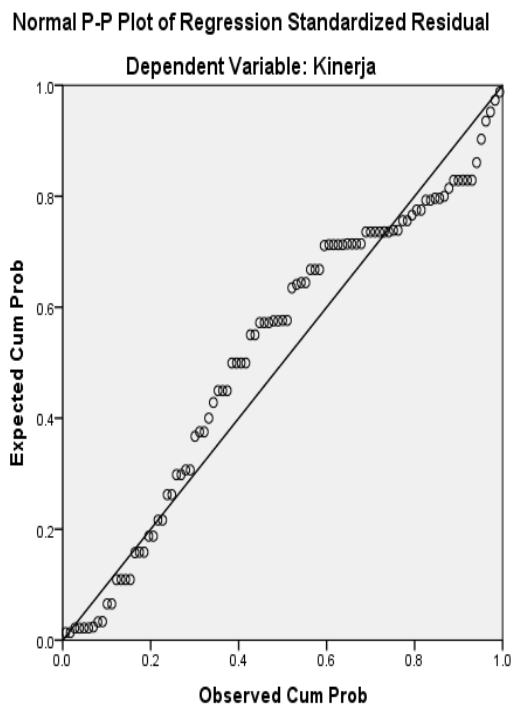

Selanjutnya uji normalitas data juga dapat menggunakan uji Kolmogorov-Smirnov Test, dengan hasil sebagai berikut.

Tabel 9

One-Sampel Kolmogorov-Smirnov Test

\begin{tabular}{|c|c|c|}
\hline \multirow{2}{*}{\multicolumn{2}{|c|}{$\mathrm{N}$}} & Unstandardized Residual \\
\hline & & 95 \\
\hline \multirow{2}{*}{ Normal Parameters } & Mean & $0 \mathrm{E}-7$ \\
\hline & Std. Deviation & 1.830298291 \\
\hline \multirow{3}{*}{ Most Extreme Differences } & Absolute & .131 \\
\hline & Positive & .104 \\
\hline & Negative & -.131 \\
\hline \multicolumn{2}{|l|}{ Kolmogorov-Smirnov Z } & 1.279 \\
\hline \multicolumn{2}{|l|}{ Asymp. Sig. (2-tailed) } & .076 \\
\hline
\end{tabular}

Sumber : Hasil Pengolahan SPSS Versi 20

Pada Tabel 9, diatas diketahui signifikansi sebesar 0.076. Nilai signifikansi ini lebih besar dari 0.05 , sehingga dapat disimpulkan bahwa data yang diuji berdistribusi normal.

\subsubsection{Uji Multikolinearitas}

Uji multikolinieritas bertujuan untuk menguji apakah dalam model regresi ditemukan adanya korelasi antar variabel bebas (independent). Uji ini dilakukan dengan melihat nilai tolerance dan variance inflation factor (VIF) dari hasil analisis dengan menggunakan
SPSS. Apabila nilai tolerance value $>0,10$ atau VIF $<10$ maka disimpulkan tidak terjadi multikolinieritas. Uji Multikolinieritas dari hasil angket yang telah didistribusikan kepada respoden dapat dilihat pada tabel berikut.

Tabel 10

Uji Multikolinearitas

\begin{tabular}{|l|c|c|}
\hline \multirow{2}{*}{ Variabel } & \multicolumn{2}{c|}{ Collinearity Statistics } \\
\cline { 2 - 3 } & Tolerance & VIF \\
\hline Iklim Organisasi & 0.967 & 1.034 \\
\hline Motivasi kerja & 0.857 & 1.167 \\
\hline Kepuasan kerja & 0.884 & 1.132 \\
\hline
\end{tabular}


a Dependent Variable : Kinerja

Berdasarkan tabel 10 di atas dapat dilihat bahwa angka Variance Inflation Factor (VIF) lebih kecil dari 10 antara lain adalah iklim organisasi $1,034<10$, motivasi kerja $1,167<$ 10 , dan kepuasan kerja $1.132<10$, nilai Tolerance iklim organisasi $0.967>0.10$, motivasi kerja 0,857> 0,10 dan kepuasan kerja $0,884>0,10$ sehingga terbebas dari multikolinieritas.
2.5. Analisis Regresi Linear Berganda

Analisis Regresi Linier Berganda antara Variabel Iklim organisasi, Motivasi kerja dan Kepuasan kerja Terhadap kinerja pegawai di Kantor Wilayah Direktorat Jenderal Pajak Sumatera Utara I, dapat dilihat dari persamaan regresinya, dan dari output program SPSS diperoleh data sebagai berikut.

Tabel 11

Pengaruh Iklim Organisasi, Motivasi Kerja Dan Kepuasan Kerja Terhadap Kinerja Pegawai

\begin{tabular}{|c|c|c|c|c|c|c|}
\hline \multirow{2}{*}{\multicolumn{2}{|c|}{ Model }} & \multicolumn{2}{|c|}{$\begin{array}{c}\text { Unstandardized } \\
\text { Coefficients }\end{array}$} & \multirow{2}{*}{$\begin{array}{c}\text { Standardized } \\
\text { Coefficients } \\
\text { Beta } \\
\end{array}$} & \multirow{2}{*}{$\mathrm{t}$} & \multirow{2}{*}{ Sig. } \\
\hline & & $\mathrm{B}$ & Std. Error & & & \\
\hline 1 & (Constant) & 3.650 & 3.455 & & 1.056 & .294 \\
\hline & Iklim Organisasi & .119 & .055 & .132 & 2.150 & .034 \\
\hline & Motivasi kerja & .216 & .050 & .283 & 4.340 & .000 \\
\hline & Kepuasan kerja & .575 & .056 & .654 & 10.188 & .000 \\
\hline
\end{tabular}

Berdasarkan Tabel 11 diatas dapat dibuat persamaan regresi sebagai berikut :

$Y=3.650+0.119 X_{1}+0.216 X_{2}+0.575 X_{3}$

Nilai kinerja pegawai di Kantor Wilayah Direktorat Jenderal Pajak Sumatera Utara I sebesar 3.650, yang mana nilai dari variabel iklim organisasi, motivasi kerja dan kepuasan kerja diabaikan. Persamaan di atas menjelaskan bahwa koefisien regresi X1 (iklim organisasi) mempunyai nilai positif yaitu 0.119 , hal ini menunjukkan bahwa variabel iklim organisasi mempunyai pengaruh positif terhadap kinerja karyawan, bila iklim oganisasi meningkat $1 \%$, maka kinerja pegawai akan bertambah 1.19. Persamaan di atas menjelaskan bahwa koefisien regresi X2 (motivasi kerja) mempunyai nilai positif yaitu 0.216 , hal ini menunjukkan bahwa variabel motivasi kerja mempunyai pengaruh positif terhadap kinerja pegawai, bila motivasi

Tabel 12

Uji Simultan (Uji F)

\begin{tabular}{|l|l|r|r|r|r|c|}
\hline \multirow{2}{*}{ Model } & & $\begin{array}{c}\text { Sum of } \\
\text { Squares }\end{array}$ & \multicolumn{1}{c|}{ df } & $\begin{array}{c}\text { Mean } \\
\text { Square }\end{array}$ & \multicolumn{1}{c|}{ F } & Sig. \\
\hline \multirow{4}{*}{1} & Regression & 636.827 & 3 & 212.276 & 61.344 & $.000^{\mathrm{a}}$ \\
\cline { 2 - 7 } & Residual & 314.899 & 91 & 3.460 & & \\
\cline { 2 - 7 } & Total & 951.726 & 94 & & & \\
\hline
\end{tabular}

a Predictors: (Constant), Iklim, Motivasi, Kepuasan

Berdasarkan tabel 12 di atas dapat dilihat bahwa Fhitung sebesar 61.344 sedangkan Ftabel sebesar 2,72 dengan nilai probabilitas kerja meningkat $1 \%$, maka kinerja pegawai akan bertambah 21.6. Persamaan di atas menjelaskan bahwa koefisien regresi X3 (kepuasan kerja) mempunyai nilai positif yaitu 0.575, hal ini menunjukkan bahwa variabel kepuasan kerja mempunyai pengaruh positif terhadap kinerja pegawai, bila kepuasan kerja meningkat $1 \%$, maka kinerja pegawai akan bertambah 57.5 .

\subsection{Uji Signifikan Simultan (Uji F)}

Uji F (uji simultan) dilakukan untuk melihat pengaruh variabel bebas terhadap variabel terikatnya secara serempak. Cara yang digunakan adalah dengan melihat level of significant $(=0,05)$. Jika nilai signifikansi lebih kecil dari 0,05 maka $\mathrm{H} 0$ ditolak dan $\mathrm{Ha}$ diterima. 
ini iklim organisasi, motivasi kerja dan kepuasan kerja secara simultan berpengaruh signifikan terhadap kinerja pegawai. Maka hipotesis sebelumnya adalah Terima Ha (tolak H0) atau hipotesis diterima.

\subsection{Uji Signifikan Parsial (t)}

Uji Parsial (Uji t) menunjukkan seberapa jauh variabel bebas secara individual menerangkan variasi pengujian ini dilakukan dengan menggunakan tingkat signifikansi 5\%.

Tabel 13

Uji Parsial (Uji t)

\begin{tabular}{|c|c|c|c|c|c|c|}
\hline \multirow{2}{*}{\multicolumn{2}{|c|}{ Model }} & \multicolumn{2}{|c|}{$\begin{array}{l}\text { Unstandardized } \\
\text { Coefficients }\end{array}$} & \multirow{3}{*}{$\begin{array}{c}\text { Standardized } \\
\text { Coefficients } \\
\text { Beta }\end{array}$} & \multirow{2}{*}{$\mathrm{t}$} & \multirow{2}{*}{ Sig. } \\
\hline & & B & Std. Error & & & \\
\hline \multirow[t]{4}{*}{1} & (Constant) & 3.650 & 3.455 & & 1.056 & .294 \\
\hline & Iklim Organisasi & .119 & .055 & .132 & 2.150 & .034 \\
\hline & Motivasi kerja & .216 & .050 & .283 & 4.340 & .000 \\
\hline & Kepuasan kerja & .575 & .056 & .654 & 10.188 & .000 \\
\hline
\end{tabular}

Berdasarkan tabel 13 diatas dapat dilihat bahwa :

a. Pengaruh iklim organisasi terhadap kinerja pegawai. Pengujian signifikan dengan kriteria pengambilan keputusan: Ha diterima dan HO ditolak, apabila $t_{\text {hitung }}>t_{\text {tabel }}$ atau Sig. $\mathrm{t}<\alpha$, nilai $\mathrm{t}_{\text {hitung }}$ sebesar 2.150 sedangkan $\mathrm{t}_{\text {tabel }}$ sebesar 1.986 dan signifikan sebesar 0,034 , sehingga $t_{\text {hitung }} 2.150>t_{\text {tabel }} 1.986$ dan signifikan $0,034<0,05$, maka Ha diterima dan H0 ditolak, yang menyatakan iklim organisasi secara parsial berpengaruh positif dan siginifikan terhadap kinerja pegawai.

b. Pengaruh motivasi kerja terhadap kinerja pegawai. Pengujian signifikan dengan kriteria pengambilan keputusan: Ha diterima dan $\mathrm{H} 0$ ditolak, apabila $t_{\text {hitung }}>t_{\text {tabel }}$ atau Sig. $\mathrm{t}<\alpha$, nilai $\mathrm{t}_{\text {hitung }}$ sebesar 4.340 sedangkan $\mathrm{t}_{\text {tabel }}$ sebesar 1.986 dan signifikan sebesar 0,000 , sehingga $t_{\text {hitung }} 4.340>t_{\text {tabel }} 1.986$ dan signifikan $0,000<0,05$, maka Ha diterima dan $\mathrm{H} 0$ ditolak, yang menyatakan motivasi kerja secara parsial berpengaruh positif dan siginifikan terhadap kinerja pegawai.

c. Pengaruh kepuasan kerja terhadap kinerja pegawai. Pengujian signifikan dengan kriteria pengambilan keputusan: Ha diterima dan HO ditolak, apabila $t_{\text {hitung }}>t_{\text {tabel }}$ atau Sig. $\mathrm{t}<\alpha$, nilai $\mathrm{t}_{\text {hitung }}$ sebesar 10.188 sedangkan $\mathrm{t}_{\text {tabel }}$ sebesar 1.986 dan signifikan sebesar 0,000 , sehingga $t_{\text {hitung }} 10.188>t_{\text {tabel }} 1.986$ dan signifikan $0,000<0,05$, maka $\mathrm{Ha}$ diterima dan $\mathrm{HO}$ ditolak, yang menyatakan motivasi kerja secara parsial berpengaruh positif dan siginifikan terhadap kinerja pegawai.

\subsection{Koefisien Determinasi}

Analisis koefisien determinasi ini digunakan untuk mengetahui persentase besarnya variasi pengaruh variabel bebas terhadap variabel terikat.

Tabel 14

Uji Determinasi

\begin{tabular}{|l|c|r|r|r|}
\hline Model & $\mathrm{R}$ & R Square & $\begin{array}{c}\text { Adjusted R } \\
\text { Square }\end{array}$ & \multicolumn{1}{c|}{ Std. Error of the Estimate } \\
\hline 1 & $.818^{\mathrm{a}}$ & .669 & .658 & 1.86022 \\
\hline
\end{tabular}

a Predictors: (Constant), Iklim, Motivasi, Kepuasan

Dependent Variable: Kinerja

Berdasarkan tabel 14 di atas menunjukkan bahwa angka adjusted $R$ Square 0,658 yang disebut koefisien determinasi dan artinya bahwa 65.8\% kinerja pegawai dapat diperoleh dan dijelaskan oleh iklim organisasi, motivasi kerja dan kepuasan kerja. Sedangkan sisanya $100 \%$ $65.8 \%=34,2 \%$ dijelaskan oleh faktor lain atau variabel diluar model.

\section{Kesimpulan}

Berdasarkan pada analisis dan evaluasi data di atas, maka kesimpulan dari penelitian ini adalah :

1. Variabel iklim organisasi berpengaruh positif dan signifikan terhadap kinerja pegawai Kantor Wilayah Direktorat Jenderal 
Pajak Sumut I dengan nilai t hitung > t table $(2.150>1.986)$ dan nilai signifikansi $(0.034$ $<0.05)$

2. Variabel motivasi kerja berpengaruh positif dan signifikan terhadap kinerja pegawai Kantor Wilayah Direktorat Jenderal Pajak Sumut I dengan nilai $\mathrm{t}$ hitung $>\mathrm{t}$ table $(4.340>1.986)$ dan nilai signifikansi $(0.000$ $<0.05)$

3. Variabel kepuasan kerja berpengaruh positif dan signifikan terhadap kinerja pegawai Kantor Wilayah Direktorat Jenderal Pajak Sumut I dengan nilai $\mathrm{t}$ hitung $>\mathrm{t}$ table $(10.188>1.986)$ dan nilai signifikansi $(0.000<0.05)$

4. Variabel iklim organisasi, motivasi kerja dan kepuasan kerja berpengaruh positif dan signifikan terhadap kinerja pegawai Kantor Wilayah Direktorat Jenderal Pajak Sumut I dengan nilai $\mathrm{F}$ hitung $>\mathrm{F}$ table (61.344 > 2.72) dan nilai signifikansi $(0.000<0.05)$

\section{DAFTAR PUSTAKA}

Abdullah, Z., Darwanis., dan Zein, B. (2013). Pengaruh Stres Kerja terhadap Kinerja Auditor Melalui Motivasi Kerja sebagai Variabel Intervening. Jurnal Akuntansi, Volume 2, No. 1, November 2012

Altangerel, O., Ruimei, W., Elahi, E., dan Dash, B. (2015). Investigating The Effect Of Job Stress and Motivation On Performance of Employees. International Journal of Scientific \& technology research Vol 4 Issue 02.

Anwar, A.B., Maupa, H., Ali, M., dan Ismail, M. (2015). The Effects of Work Stress and Compensation on the Employees' Performance through Motivation and Job Satisfaction at the Private Life Insurance Companies in Jakarta, Indonesia. Scientific Research Journal (SCIRJ), Volume III, Issue IX

Arief, C.A., dan Farid, W. (2011). Pengaruh Kepemimpinan, Stres Kerja, Disiplin Kerja dan Kompensasi terhadap Kinerja Pegawai. Jurnal Ekonomi Manajemen Sumber Daya Vol. 12, No. 1

Arikunto, Suharsismi. (2002). Prosedur Penelitian Suatu Pendekatan Praktek. Jakarta: Rineka Cipta.

Azmi, F.S., Shahid, S.A., dan Alwi, A. (2016). The Relationship between Job Stress and Front-liners' Job Performance in a Shared Service Center in Malaysia. International
Journal of Social Science and Humanity, Vol. 6, No. 7.

Cross, T.M dan Lynch. R.R. (2002). Peniliaian dan Evaluasi Kinerja: Konsep dan Praktik. Jakarta. Penerbit Ghalia Indonesia

David, Fred. R (2001), The Balanced Scorecard, Scientific Research Journal (SCIRJ),

Dessler, Gary. (2007). Manajemen Sumber Daya Manusia (Jilid I). Jakarta : Indeks.

Fauzi, A. (2013). Pengaruh Kepemimpinan, Kecerdasan Emosional dan Motivasi terhadap Kepuasan Kerja Guru di SMA. Jurnal Manajemen Pendidikan Vol 1, No 1

Hasibuan, Malayu S. P. (2008). Manajemen Sumber Daya Manusia. Edisi Revisi Jakarta: PT. Bumi Aksara.

Mahiri, E., dan Orwa, B.H. (2016). Occupational Stress and Employee Performance: A Case Study of Kenya National Highways Authority (KeNHA). International Journal of Education and Research Vol. 4 No. 1

Mangkunegara, Anwar, Prabu. (2009). Evaluasi Kinerja SDM, Cetakan 4, Bandung : Refika Aditama

Mangkuprawira, Sjafri. (2004). Manajemen Sumber Daya Manusia Strategik. Cetakan ketiga, Penerbit Ghalia Indonesia

Noviansyah dan Zunaidah (2011). Pengaruh Kepuasan Kerja Dan Motivasi Kerja Terhadap Kinerja Pegawai PT. Perkebunan Minanga Ogan Baturaja. Jurnal Manajemen dan Bisnis Sriwijaya Vol.9 No.18.

Riduwan. (2007). Skala Pengukuran VariabelVariabel Bandung : Alfabeta

Robbins S.P \& Judge,T.A. 2007. Perilaku Organisasi. Buku 1 Edisi 12. Terjemahan Diana Angelica. Penerbit Salemba Empat. Jakarta.

Robbins, Stephen P. (2006). Perilaku Organisasi. Edisi kesepuluh. Jakarta: Indeks Kelompok Gramedia.

Rosneli dan Septiani (2008). Pengaruh Stres Kerja terhadap Kinerja Pegawai pada bagian Redaksi Surat kabar Harian Umum Lampung Post. Jurnal Bisnis dan Manajemen Vol 4 No 2

Rush, Michael dan Althoff, Phillip. (2003). Pengantar Sosiologi Politik. Jakarta: PT. Raja Grafindo Persada. 
Samsudin, Sadili. (2009). Manajemen Sumber Daya Manusia. Bandung: CV. Pustaka Setia.

Sedarmayanti. (2004). Good Governance (Kepemerintahan Yang Baik), Bandung : Mandar Maju

Sekaran, U., dan Bougie (2010), Research Methods for Busines. A Skill Building Approach. Fifth Edition. A John Wiley and Sons, Ltd, Publication.

Siagian, Sondang. (2008). Manajemen Sumber Daya Manusia (cetakan 15). Jakarta: Bumi Aksara

Sink, R dan Tuttle, J.K. (2008). Evaluasi Kinerja. Jakarta: Indeks Kelompok Gramedia.

Sugiyono. (2009). Metode Penelitian Kuantitatif dan Kualitatif dan R \& D. Bandung : Alfabeta

Suliyanto. (2011). Ekonometrika Terapan : Teori \& Aplikasi dengan SPSS. CV Andi Offset

Thoha, Miftah. (2001). Birokrasi Indonesia Dalam Era Globalisasi, Pusdiklat
Pegawai Depdiknas, Sawangan, Bogor.

Terry George dan Rue, Leslie W alih bahasa Sadeli (2011), Dasar-Dasar Manajemen, Cetakan Ketujuh Bumi Aksara Jakarta.

Triton PB (2005), Paradigma Baru Manajemen Sumber Daya Manusia, Tugu Yogyakarta. (2006), SPSS 12.00 Terapan Riset Statistik Parametrik, Andi Yogyakarta.

Yukl, G. 2007.Kepemimpinan Dalam Organisasi.Edisi Indonesia (kelima). Cetakan kedua. Penerbit PT Indeks, Jakarta.

Zauhar. S. 2001. Reformasi Birokrasi. Universitas Brawijaya Malang

Peraturan Pemerintah No. 100 Tahun 2000, Tentang Pengangkatan Pegawai Negeri Sipil Dalam Jabatan Struktural. 